\title{
PENGARUH LAMA PERKECAMBAHAN MILLET (Panicum milliaceum) TERHADAP KARAKTERISTIK FLAKES
}

The Effect of Germination Time of Millet (Panicum Milliaceum) on The Characteristics of Flakes

\author{
I Gusti Agung Ayu Sintia Padma Dewi ${ }^{1)}$, I Gusti Ayu Ekawati ${ }^{2}$, I Desak Putu Kartika Pratiwi ${ }^{2)}$ \\ ${ }^{1)}$ Mahasiswa Program Studi Ilmu dan Teknologi Pangan, Fakultas Teknologi Pertanian, Unud \\ ${ }^{2}$ Dosen Program Studi Ilmu dan Teknologi Pangan, Fakultas Teknologi Pertanian, Unud \\ Kampus Bukit Jimbaran, Badung-Bali
}

\begin{abstract}
The purpose of this research was to know the effect of germination time of millet (Panicum milliaceum) on the characteristics of flakes and to know the right germination time of millet on the characteristics of flakes. The experimental design used was completely randomized design with the germination time of millet treatment, namely 24 hours (T1), 48 hours (T2), 72 hours (T3), 96 hours (T4), and 120 hours (T5). The treatment was repeated 3 repetitions then obtained 15 units of the experiment, the data obtained from the result were analyzed by variance and if the treatment had an effect on the variable then continued with Duncan test. The results showed that the germination of millet had significant effect to water content, ash content, protein content, fat content, crude fiber content, tannin content, taste level (hedonic test), and overall acceptance of flakes. 120 hours germination time of millet had the best characteristics with water content 1,36\%, ash content 2,65\%, protein content $9,93 \%$, fat content $7,86 \%$, carbohydrate content $78,20 \%$, crude fiber content 5,93 , tannin content $0,31 \%$, color liked, flavor liked, texture crispy and liked, taste liked and overall acceptance liked.
\end{abstract}

Keywords : millet, sprouts millet, germination time

\section{PENDAHULUAN}

Pola konsumsi pangan masyarakat di era modern ini telah mengalami perubahan, yaitu masyarakat cenderung memilih makanan yang praktis tanpa mengurangi pemenuhan kebutuhan gizi. Sereal sarapan cepat saji kini menjadi pilihan masyarakat untuk memenuhi kebutuhan makanan yang memiliki kandungan gizi lengkap dan praktis. Salah satu sereal sarapan cepat saji yang beredar di pasaran yaitu flakes. Flakes adalah makanan sarapan siap saji yang telah dikembangkan di banyak negara dan banyak dikonsumsi masyarakat. Bahan baku pembuatan flakes pada umumnya adalah terigu. Millet merupakan salah satu alternatif bahan pengganti terigu.
Millet adalah serealia berbiji kecil yang memiliki nilai kandungan gizi yang mirip dengan tanaman serealia lainnya seperti padi, jagung, dan gandum. Di Indonesia sebagian besar masyarakat belum mengenal millet sebagai sumber pangan sehingga selama ini tanaman millet hanya dijadikan sebagai pakan burung. Tanaman ini dapat diolah menjadi sumber makanan oleh masyarakat guna mendukung ketahanan pangan dan mengantisipasi masalah kelaparan. Millet juga mengandung berbagai gizi yaitu dalam $100 \mathrm{~g}$ millet terdapat protein $13,4 \%$, serat kasar 6,3\%, dan pati 67,1\% (Abate dan Gomez, 1984). Menurut Rooney dan Serna (2000), millet memiliki senyawa tanin yang merupakan golongan senyawa fenolik.

*Korespondensi Penulis:

Email: geksin1504@gmail.com ${ }^{1}$ 
Senyawa tanin ini dapat menyebabkan rasa pahit pada produk olahan millet sehingga dapat menurunkan daya terima. Terdapat beberapa cara untuk mengurangi rasa pahit yang disebabkan oleh tanin yang terdapat pada millet, seperti proses perkecambahan, fermentasi, dan perendaman dengan senyawa kimia.

Proses perkecambahan dipilih sebagai proses untuk menurunkan kadar tanin pada millet karena lebih efisien dibandingkan dengan proses fermentasi dan perendaman menggunakan bahan kimia. Onyango et al. (2013), mengatakan bahwa proses perkecambahan secara signifikan dapat menurunkan kandungan antinutrisi seperti tanin. Perkecambahan memberikan efek penurunan kadar fenolik sebesar 40\% (Morero, 1989 dalam Narsih et al., 2008). Perbaikan daya cerna protein setelah perkecambahan, perendaman, dan pemanasan kering dapat dihubungkan pada penurunan antinutrisi seperti asam fitat, tanin, serta polifenol yang dikenal berinteraksi dengan protein dalam bentuk kompleks (Hassan et al., 2006). Untuk meningkatkan pemanfaatan dari kecambah millet, maka dapat diolah menjadi tepung. Tepung kecambah millet ini didapat dari proses penggilingan kecambah millet. Tepung kecambah millet dapat digunakan sebagai bahan baku dalam pembuatan flakes dan dapat memperpanjang masa simpan dari millet. Selain itu tepung kecambah millet bebas gluten sehingga aman dikonsumsi bagi orang yang menderita celiac disease (intoleransi gluten) yang mana mereka tidak bisa mengonsumsi bahan makanan yang mengandung gluten seperti gandum (Sarita dan Singh, 2016).

Berdasarkan uraian di atas maka dilakukan penelitian mengenai Pengaruh Lama Perkecambahan Millet (Panicum milliaceum) terhadap Karakteristik Flakes.

\section{METODE PENELITIAN}

\section{Tempat dan Waktu}

Penelitian ini dilaksanakan di Laboratorium Pengolahan Pangan, Laboratorium Analisis Pangan dan Laboratorium Rekayasa Proses dan Pengendalian Mutu, Fakultas Teknologi Pertanian, Universitas Udayana. Waktu pelaksanaan mulai bulan Oktober sampai dengan bulan Desember 2017.

\section{Bahan dan Alat}

Bahan - bahan yang digunakan dalam melaksanakan penelitian ini terdiri dari bahan baku, bahan tambahan, dan bahan kimia. Bahan baku yang digunakan yaitu millet dengan jenis proso millet yang diperoleh dari pasar burung Satria, Denpasar. Gula halus (Orchid), garam (Cap Jago), susu bubuk skim (UD Fenny), margarin (Blue Band), dan air (Aqua). Bahan kimia yag digunakan dalam melakukan analisis proksimat meliputi $\mathrm{H}_{2} \mathrm{SO}_{4}$, $\mathrm{NAOH}, \mathrm{HCl}$, Heksan, tablet Kjeldahl, asam borat, dan indikator PP, dan untuk analisis kadar tanin meliputi asam tanat, follin dennis, $\mathrm{Na}_{2} \mathrm{CO}_{3}$.

Alat - alat yang digunakan dalam melaksanakan penelitian ini antara lain waskom, loyang, alat penggilingan, timbagan analitik (Shimadzu), timbangan, oven (Memmert), ayakan 80 mesh, kertas saring, erlenmeyer (Pyrex), cawan porselin, aluminium foil, botol timbang, lumping, tabung reaksi (Pyrex), batang pengaduk, desikator, pompa karet, corong plastik, corong kaca, pipet tetes, pipet volume (Pyrex), labu takar (Pyrex), biuret (Pyrex), muffle (Daihan), destilator, spektrofotometer, gelas ukur (Pyrex), vortex (Maxi Mix II Type 367000), mikropipet (Socorex), tip, cuvett (Quartz), labu kjeldahl (Pyrex), soxhlet, waterbath, destruktor, kompor listrik, spektrofotometer (Thermo Scientific Genesis $10 S$ UV-Vis), perangkat komputer dan lembar quisioner.Selain itu untuk evaluasi sensoris produk, alat yang digunakan adalah piring 
kertas dan sendok.

\section{Rancangan Percobaan}

Rancangan penelitian yang dipakai dalam penelitian ini adalah Rancangan Acak Lengkap (RAL) dengan perlakuan lama perkecambahan terdiri dari 5 level yaitu: T1 (lama perkecambahan 24 jam), T2 (lama perkecambahan 48 jam), T3 (lama perkecambahan 72 jam), T4 (lama perkecambahan 96 jam), T5 (lama perkecambahan 120 jam). Masing - masing perlakuan diulang sebanyak 3 kali, sehingga didapat 15 unit percobaan. Data yang diperoleh dari hasil penelitian dianalisis dengan sidik ragam (ANOVA) dan apabila perlakuan berpengaruh terhadap variabel maka dilanjutkan dengan uji Duncan's Multiple Range Test (DMRT) (Gomes dan Gomes, 1995). Perlakuan terbaik diperoleh dari uji kimia dan sifat sensoris flakes.

\section{Pelaksanaan Penelitian}

\section{Proses Pembuatan Tepung Kecambah Millet}

Biji millet sebanyak $500 \mathrm{~g}$ terlebih dahulu dicuci sampai bersih kemudian direndam selama 12 jam. Keesokan paginya air rendaman ditiriskan dan millet diletakkan pada wadah tertutup yang dilapisi daun pisang dan dikecambahkan sesuai dengan perlakuan yaitu 24 jam, 48 jam, 72 jam, 96 jam, dan 120 jam. Selama proses perkecambahan setiap 12 jam millet disiram dengan air sebanyak $50 \mathrm{ml}$ secara merata. Millet yang sudah berkecambah kemudian dikeringkan dengan menggunakan oven selama 2 jam pada suhu $60^{\circ} \mathrm{C}$. Kecambah millet yang sudah kering kemudian dihaluskan menggunakan blender dan diayak menggunakan ayakan 80 mesh sehingga didapatkan tepung kecambah millet.

\section{Proses Pembuatan Flakes}

Tepung kecambah millet ditimbang sebanyak 100 g kemudian dicampur dengan bahan tambahan dengan formulasi gula halus $30 \%$, garam $1 \%$, margarin $5 \%$, susu bubuk skim 10\%, dan air 40\% (Fitriana et al., 2013) sehingga membentuk adonan. Adonan yang sudah jadi kemudian diambil sedikit demi sedikit dan dipipihkan menggunakan tangan. Setelah itu adonan ditipiskan menggunakan alat penggiling sehingga didapatkan lembaran adonan yang berukuran $\pm 1 \mathrm{~mm}$. Lembaran adonan yang sudah jadi kemudian diletakkan di atas loyang aluminium dan dipanggang dalam oven selama 10 menit pada suhu $120^{\circ} \mathrm{C}$. Setelah matang, flakes yang masih dalam bentuk lembaran kemudian diremukkan sehingga terbentuk remahan - remahan kecil.

\section{Variabel yang Diamati}

Variabel yang diamati dalam penelitian ini adalah kadar air dengan metode pengeringan, kadar abu dengan metode pengabuan, kadar protein dengan metode mikro-kjeldahl, kadar lemak dengan metode soxhlet, kadar karbohidrat metode by difference, kadar serat kasar, kadar tanin dengan metode spektrofotometri (Sudarmadji et al., 1997), dan evaluasi sensoris menggunakan uji hedonik terhadap warna, aroma, tekstur, rasa dan penerimaan keseluruhan serta uji skoring terhadap aroma, tekstur dan rasa (Soekarto, 1985).

\section{HASIL DAN PEMBAHASAN}

Karakteristik bahan baku seperti kadar air, kadar abu, kadar protein, kadar lemak, dan kadar karbohidrat tepung kecambah millet dapat dilihat pada Tabel 1 . 
Tabel 1. Karakteristik Tepung Kecambah Millet

\begin{tabular}{ccccccc}
\hline Perlakuan & $\begin{array}{c}\text { Kadar Air } \\
(\%)\end{array}$ & $\begin{array}{c}\text { Kadar Abu } \\
(\%)\end{array}$ & $\begin{array}{c}\text { Kadar Protein } \\
(\%)\end{array}$ & $\begin{array}{c}\text { Kadar Lemak } \\
(\%)\end{array}$ & $\begin{array}{c}\text { Kadar Karbohidrat } \\
(\%)\end{array}$ & $\begin{array}{c}\text { Rendemen } \\
(\%)\end{array}$ \\
\hline T1 (24 jam) & 7,39 & 2,56 & 8,67 & 9,08 & 72,30 & 62 \\
T2 (48 jam) & 7,53 & 2,59 & 8,85 & 9,02 & 72,01 & 60,5 \\
T3 (72 jam) & 7,79 & 2,62 & 8,89 & 8,75 & 71,95 & 63 \\
T4 (96 jam) & 8,15 & 2,63 & 9,20 & 7,91 & 72,11 & 65 \\
T5 (120 & 8,35 & 2,65 & 9,77 & 7,57 & 71,66 & 63,5 \\
jam) & & & & & \\
\hline
\end{tabular}

Nilai rata - rata kadar air, kadar abu, kadar protein, kadar lemak, dan kadar karbohidrat flakes yang dihasilkan pada perlakuan lama perkecambahan millet dapat dilihat pada Tabel
2 dan nilai rata - rata hasil analisisis kadar serat kasar, kadar tanin flakes yang dihasilkan pada perlakuan lama perkecambahan millet dapat dilihat pada Tabel 3.

Tabel 2. Nilai Rata-rata Kadar Air, Kadar Abu, Kadar Protein, Kadar Lemak, Kadar Karbohidrat, Flakes yang Dihasilkan pada Perlakuan Lama Perkecambahan Millet

\begin{tabular}{lccccc}
\hline \multirow{2}{*}{ Perlakuan } & $\begin{array}{c}\text { Kadar Air } \\
(\%)\end{array}$ & $\begin{array}{c}\text { Kadar Abu } \\
(\%)\end{array}$ & $\begin{array}{c}\text { Kadar Protein } \\
(\%)\end{array}$ & $\begin{array}{c}\text { Kadar Lemak } \\
(\%)\end{array}$ & $\begin{array}{c}\text { Kadar Karbohidrat } \\
(\%)\end{array}$ \\
\hline T1 $(24$ jam $)$ & $0,89 \mathrm{c}$ & $2,54 \mathrm{c}$ & $8,49 \mathrm{c}$ & $9,40 \mathrm{a}$ & $78,79 \mathrm{a}$ \\
T2 $(48$ jam) & $0,99 \mathrm{bc}$ & $2,57 \mathrm{bc}$ & $9,04 \mathrm{~b}$ & $9,29 \mathrm{a}$ & $78,10 \mathrm{a}$ \\
T3 $(72$ jam) & $1,09 \mathrm{abc}$ & $2,58 \mathrm{~b}$ & $9,41 \mathrm{ab}$ & $8,74 \mathrm{~b}$ & $78,22 \mathrm{a}$ \\
T4 $(96$ jam) & $1,20 \mathrm{ab}$ & $2,63 \mathrm{a}$ & $9,69 \mathrm{a}$ & $7,97 \mathrm{c}$ & $78,52 \mathrm{a}$ \\
T5 $(120$ jam $)$ & $1,36 \mathrm{a}$ & $2,65 \mathrm{a}$ & $9,93 \mathrm{a}$ & $7,86 \mathrm{c}$ & $78,20 \mathrm{a}$ \\
\hline
\end{tabular}

Keterangan : Nilai rata - rata yang diikuti oleh huruf yang berbeda pada kolom yang sama menunjukkan berbeda nyata $(\mathrm{P}<0,05)$

Tabel 3. Nilai Rata - rata Kadar Serat Kasar, Kadar Tanin Flakes yang Dihasilkan pada Perlakuan Lama Perkecambahan Millet

\begin{tabular}{lcc}
\hline \multirow{2}{*}{ Perlakuan } & Kadar & Kadar Tanin $(\%)$ \\
\hline T1 $(24$ jam) & Serat Kasar $(\%)$ & $0,40 \mathrm{a}$ \\
T2 $(48$ jam) & $4,34 \mathrm{c}$ & $0,40 \mathrm{a}$ \\
T3 (72 jam) & $4,36 \mathrm{c}$ & $0,39 \mathrm{a}$ \\
T4 (96 jam) & $4,74 \mathrm{bc}$ & $0,34 \mathrm{ab}$ \\
T5 (120 jam) & $5,13 \mathrm{ab}$ & $0,31 \mathrm{~b}$ \\
\hline
\end{tabular}

Keterangan : Nilai rata - rata yang diikuti oleh huruf yang berbeda pada kolom yang sama menunjukkan berbeda nyata $(\mathrm{P}<0,05)$

\section{Kadar Air}

Hasil sidik ragam menunjukkan bahwa lama perkecambahan millet berpengaruh nyata terhadap kadar air flakes $(\mathrm{P}<0,05)$. Tabel 2 menunjukkan kadar air berkisar antara $0,89 \%$ $1,36 \%$. Kadar air terendah flakes sebesar $0,89 \%$ yaitu pada perlakuan T1, sedangkan kadar air tertinggi sebesar $1,36 \%$ pada perlakuan T5. Berdasarkan analisis bahan baku kadar air tepung kecambah millet berada pada kisaran 7,39\% - 8,35\% , dimana T1 memiliki kadar air terendah yaitu sebesar 7,39\% dan T5 memiliki kadar air tertinggi yaitu sebesar $8,35 \%$. Kadar air dari bahan baku mempengaruhi kadar air dari flakes yang dihasilkan. Tingginya kadar air flakes pada perlakuan T5 disebabkan karena selama proses perkecambahan dilakukan penyiraman secara merata setiap 12 jam, sehingga semakin lama dikecambahkan maka air yang diserap 
semakin banyak. Menurut Anggrahini (2007), makin lama waktu inkubasi pada perkecambahan kacang hijau maka kandungan air kecambah kacang hijau makin meningkat karena selama proses inkubasi dilakukan proses penyiraman sehingga terjadi penyerapan air yang menyebabkan terjadinya peningkatan kadar air kecambah kacang hijau.

\section{Kadar Abu}

Hasil sidik ragam menunjukkan bahwa lama perkecambahan berpengaruh sangat nyata terhadap kadar abu flakes $(\mathrm{P}<0,01)$. Tabel 2 menunjukkan kadar abu flakes terendah diperoleh pada perlakuan T1 yaitu 2,54\%, sedangkan kadar abu tertinggi flakes diperoleh pada perlakuan T5 yaitu 2,65\% dan tidak berbeda dengan perlakuan T4. Peningkatan kadar abu flakes disebabkan karena makin lamanya waktu perkecambahan maka terjadi peningkatan kadar mineral. Peningkatan kadar mineral terjadi seiring dengan peningkatan aktivitas enzim fitase selama perkecambahan yang menyebabkan hidrolisis ikatan antara protein-enzim mineral menjadi bebas sehingga meningkatkan ketersediaan mineral (Inyang dan Zakari, 2008). Sesuai dengan penyataan Ikujenlola dan Fashakin (2005) dikatakan bahwa kadar mineral meningkat pesat pada tepung beras, kacang tunggak, dan jagung yang berkecambah, seperti kalsium, potassium, phosphor, besi, seng, dan sodium.

\section{Kadar Protein}

Hasil sidik ragam menunjukkan bahwa lama perkecambahan millet berpengaruh sangat nyata terhadap kadar protein flakes $(\mathrm{P}<0,01)$. Tabel 2 menunjukkan kadar protein terendah flakes diperoleh pada perlakuan $\mathrm{T} 1$ yaitu $8,49 \%$, sedangkan kadar protein tertinggi flakes diperoleh pada perlakuan T5 yaitu 9,93\% dan tidak berbeda dengan perlakuan T4. Kadar protein flakes meningkat seiring dengan semakin lamanya perkecambahan, hal tersebut disebabkan karena selama proses perkecambahan terjadi pembentukan asam amino yang merupakan penyusun dari protein. Menurut Inyang dan Zakari (2008) selama perkecambahan terjadi pemecahan ikatan peptida oleh enzim protease yang menghasilkan asam amino. Perombakan senyawa kompleks menjadi senyawa yang lebih sederhana terjadi selama proses perkecambahan.

\section{Kadar Lemak}

Hasil sidik ragam menunjukkan bahwa lama perkecambahan millet berpengaruh sangat nyata terhadap kadar lemak flakes $(\mathrm{P}<0,01)$. Tabel 2 menunjukkan kadar lemak terendah flakes diperoleh pada perlakuan T5 yaitu 7,86\% dan tidak berbeda dengan perlakuan T4, sedangkan kadar lemak tertinggi flakes diperoleh pada perlakuan $\mathrm{T} 1$ yaitu 9,40\% dan tidak berbeda dengan perlakuan T2. Kadar lemak pada flakes menurun seiring dengan lamanya waktu perkecambahan disebabkan karena selama proses perkecambahan terjadi hidrolisis lemak menjadi komponen lebih sederhana dan digunakan sebagai sumber energi untuk berkecambah. Hal ini sesuai dengan pernyataan Kruger (1991) dalam Satyati (2001) bahwa selama perkecambahan terjadi penurunan lemak dan peningkatan enzim lipase.

\section{Kadar Karbohidrat}

Hasil sidik ragam menunjukkan bahwa lama perkecambahan millet tidak berpengaruh nyata terhadap kadar karbohidrat flakes $(\mathrm{P}<0,05)$. Tabel 2 menunjukkan bahwa kadar karbohidrat berkisar antara 78,10\% pada T1 $78,79 \%$ pada T5.

\section{Kadar Serat Kasar}

Hasil sidik ragam menunjukkan bahwa lama perkecambahan millet berpengaruh sangat nyata terhadap kadar serat kasar flakes $(\mathrm{P}<0,01)$. Tabel 3 menunjukkan kadar serat kasar terendah flakes diperoleh dari perlakuan 
T1 yaitu 4,34\% dan tidak berbeda dengan perlakuan $\mathrm{T} 2$, sedangkan kadar serat kasar tertinggi flakes diperoleh dari perlakuan T5 yaitu $5,93 \%$. Kadar serat kasar meningkat seiring dengan lamanya waktu perkecambahan, hal ini disebabkan karena terjadinya perubahan komponen pembentuk karbohidrat seperti selulosa dan hemiselulosa yang merupakan komponen terbesar dinding sel (Shah et al., 2011). Ini juga dukung oleh pernyataan Megat et al. (2016) bahwa terjadi peningkatan secara signifikan terhadap kadar serat pangan pada legume, kacang merah, kacang hijau, kacang kedelai setelah proses perkecambahan. Meningkatnya kadar serat pangan berbanding lurus dengan meningkatkan kadar serat kasar, karena serat pangan merupakan bagian dari serat kasar.

\section{Kadar Tanin}

Hasil sidik ragam menunjukkan bahwa lama perkecambahan millet berpengaruh nyata terhadap kadar tanin flakes $(\mathrm{P}<0,05)$. Tabel 3 menunjukkan kadar tanin terendah flakes diperoleh dari perlakuan T5 yaitu 0,31\%, sedangkan kadar tanin tertinggi flakes diperoleh dari perlakuan T1 yaitu $0,40 \%$ dan tidak berbeda dengan perlakuan T2 dan T3.
Kadar tanin pada millet sebelum dikecambahkan sebesar $0,61 \%$ (Sarita dan Singh, 2016). Kadar tanin menurun seiring dengan lamanya waktu perkecambahan dikarenakan tanin dapat larut dalam air dan tanin akan mengalami perombahkan akibat proses perkecambahan. Perkecambahan akan mengakibatkan degradasi komponen bahan bahan yang mengakibatkan perubahan sturktur molekul seperti asam fitat, tanin, protein dan senyawa lainnya (Sukamto, 1992 dalam Narsih et al. 2008). Hal ini juga didukung oleh pernyataan Hassan et al. (2006) bahwa selama proses perkecambahan terjadi penurunan antinutrisi seperti asam fitat, tanin, dan polifenol.

\section{Evaluasi Sifat Sensoris}

Evaluasi sifat sensoris flakes dilakukan dengan uji hedonik terhadap warna, aroma, tekstur, rasa dan penerimaan keseluruhan. Uji skoring dilakukan terhadap rasa dan tekstur flakes. Nilai rata-rata uji hedonik terhadap warna, aroma, tekstur, rasa dan penerimaan keseluruhan flakes dapat dilihat pada Tabel 4. Nilai rata-rata uji skoring terhadap rasa dan tekstur flakes dapat dilihat pada pada Tabel 5.

Tabel 4. Nilai rata - rata Uji Hedonik Warna, Aroma, Tekstur, Rasa dan Penerimaan Keseluruhan Flakes

\begin{tabular}{lrrrrc}
\hline \multirow{2}{*}{ Perlakuan } & \multicolumn{5}{c}{ Nilai rata - rata uji hedonik } \\
\cline { 2 - 6 } & Warna & Aroma & Tekstur & Rasa & Penerimaan Keseluruhan \\
\hline T1 (24 jam) & 6,26 & 6,33 & 6,00 & 4,33 & 5,67 \\
T2 (48 jam) & 6,46 & 6,40 & 6,06 & 4,73 & 5,80 \\
T3 (72 jam) & 6,33 & 6,33 & 6,06 & 5,40 & 5,86 \\
T4 (96 jam) & 6,26 & 6,33 & 6,33 & 5,86 & 6,13 \\
T5 (120 jam) & 6,40 & 6,33 & 6,00 & 6,13 & 6,20 \\
\hline
\end{tabular}

Keterangan : Nilai rata - rata yang diikuti oleh huruf yang berbeda pada kolom yang sama menunjukkan berbeda nyata $(\mathrm{P}<0,05)$

\section{Warna}

Hasil nilai rata - rata menunjukkan bahwa lama perkecambahan millet tidak berpengaruh terhadap warna flakes. Tabel 4 menunjukkan bahwa nilai rata-rata kesukaan panelis terhadap warna flakes berkisar antara 6,26 (suka) sampai dengan 6,46 (suka).
Aroma
Hasil nilai rata - rata menunjukkan bahwa lama perkecambahan tidak berpengaruh terhadap terhadap aroma flakes. Tabel 4 
menunjukkan bahwa nilai rata-rata kesukaan panelis terhadap aroma berkisar antara 6,33

(suka) sampai dengan 6,40 (suka).

Tabel 5. Nilai rata-rata Uji Skoring Tekstur dan Rasa Flakes

\begin{tabular}{lcc}
\hline \multirow{2}{*}{ Perlakuan } & \multicolumn{2}{c}{ Nilai Rata - rata Uji Skoring } \\
\cline { 2 - 3 } & Tekstur & Rasa \\
\hline T1 (24 jam) & 4,13 & 1,40 \\
T2 (48 jam) & 4,20 & 2,20 \\
T3 (72 jam) & 4,20 & 2,80 \\
T4 (96 jam) & 4,13 & 3,73 \\
T5 (120 jam) & 4,06 & 4,87 \\
\hline Keterangan: & Nilai rata - rata yang diikuti oleh huruf yang berbeda pada kolom yang sama menunjukkn berbeda
\end{tabular}

Keterangan: Nilai rata - rata yang diikuti oleh huruf yang berbeda pada kolom yang sama menunjukkan berbeda nyata $(\mathrm{P}<0,05)$

Kriteria Tekstur : 5= sangat renyah; 4= renyah; 3= agak renyah; $2=$ tidak renyah; $1=$ sangat tidak renyah

Kriteria Rasa : 5= tidak pahit; 4= agak tidak pahit; 3= agak pahit; $2=$ pahit; $1=$ sangat pahit

\section{Tekstur}

Hasil nilai rata - rata menunjukkan bahwa lama perkecambahan millet tidak berpengaruh terhadap kesukaan tekstur (uji hedonik) flakes. Tabel 4 menunjukkan bahwa nilai rata-rata kesukaan panelis terhadap tekstur flakes berkisar antara 6 (suka) sampai dengan 6,33 (suka). Lama perkecambahan millet tidak berpengaruh terhadap tingkatan tekstur (uji skoring) flakes. Tabel 5 menunjukkan bahwa nilai rata-rata penerimaan terhadap tekstur uji skoring flakes berkisar antara 4,06 (renyah) sampai dengan 4,20 (renyah). Tekstur renyah flakes dipengaruhi oleh komponen pati yang terkandung dalam millet.

\section{Rasa}

Hasil sidik ragam menunjukkan bahwa lama perkecambahan millet berpengaruh sangat nyata terhadap rasa flakes $(\mathrm{P}<0,05)$. Tabel 4 menunjukkan bahwa nilai tertinggi kesukaan panelis terhadap rasa flakes yaitu pada T5 sebesar 6,13 (suka), dan nilai terendah pada T1 sebesar 4,33 (biasa). Tabel 5 menunjukkan bahwa nilai tertinggi uji skoring terhadap rasa pahit flakes yaitu pada T5 sebesar 4,87 (tidak pahit), dan nilai terendah pada $\mathrm{T} 1$ sebesar 1,40 (sangat pahit). Hal yang menyebabkan berbedanya penilian rata - rata terhadap rasa, yaitu semakin lama millet dikecambahkan maka kandungan taninnya akan berkurang. Tanin merupakan zat yang dapat menyebabkan rasa pahit pada makanan, oleh sebab itu pada perlakuan T5 mendapat nilai tertinggi dari panelis.

\section{Penerimaan Keseluruhan}

Hasil nilai rata - rata menunjukkan bahwa lama perkecambahan millet berpengaruh terhadap penerimaan keseluruhan flakes. Tabel 4 menunjukkan bahwa nilai rata-rata tingkat kesukaan panelis terhadap penerimaan keseluruhan flakes meningkat dari perlakuan T1 sebesar 5,67 (suka) dan T5 sebesar 6,20 (suka). Penerimaan keseluruhan flakes dipengaruhi oleh rasa.

\section{SIMPULAN DAN SARAN}

\section{Simpulan}

Berdasarkan hasil penelitian ini dapat disimpulkan sebagai berikut :

1. Lama perkecambahan millet berpengaruh terhadap kadar air, kadar abu, kadar protein, kadar lemak, kadar serat kasar, kadar tanin, tingkat rasa (uji hedonik), dan penerimaan keseluruhan flakes.

2. Lama perkecambahan millet selama 120 jam (T5) merupakan karakteristik terbaik flakes dengan kriteria kadar air 1,36\%, kadar abu 2,65\%, kadar protein 9,93\%, kadar lemak 7,86\%, kadar karbohidrat 78,20\%, kadar serat kasar 5,93\%, kadar tanin $0,31 \%$, warna suka, aroma suka, 
tekstur renyah dan suka, rasa tidak pahit dan suka, serta penerimaan keseluruhan suka.

\section{Saran}

Berdasarkan hasil penelitian ini disarankan untuk dilakukan penelitian lebih lanjut mengenai perbaikan tekstur dari flakes seperti penambahan bahan lain yang memiliki kandungan pati tinggi agar apabila flakes dijadikan minuman sereal atau ditambahkan dengan susu, tekstur flakes tetap renyah.

\section{DAFTAR PUSTAKA}

Abate, A. N dan M. Gomez.1984. Substitution of Finger Millet and Bulrush Millet for Maize in Boiler Feeds, Anim. Feed Sci. Tech-nol. 10:291

Anggrahini, Sri. 2007. Pengaruh Lama Pengecambahan Terhadap Kandungan $\alpha$ Tokoferol dan Senyawa Proksimat Kecambah Kacang Hijau (Phaseolus radiatus L). Jurnal Teknologi Pertanian. Vol. 27(4) : 155-156.

Fitriana, Y., Y. Atma., E. Poerwoto . 2013. Daya Terima Flakes Berbasis Bekatul dan Tepung Tempe. Artikel Penelitian Program Studi Ilmu Gizi, Fakultas Ilmu - ilmu Kesehatan, Universitas Esa Unggul Jakarta. Jakarta.

Gomes, K.A. dan A.A. Gomes. 1995. Prosedur Statistik Untuk Penelitian Pertanian. UI Press, Jakarta.

Hassan, A.B., I.A.M. Ahmed, N.M. Osman, M.M. Eltayeb, G.A. Osman, dan E.E. Babiker. 2006. Effect of processing treatments followed by fermentation on protein content and digestibility of pearl millet (Pennisetum thypoideum) cultivars. Pakistan Journal Nutr. 5(1): 86-89.

Ikujenlola, V.A, dan Fashakin, JB. 2005. The Physico-chemical Properties of a Complementary Diet Prepared from Vegetable Proteins. Journal of Food
Agriculture and Environment Vol.3 (3\&4) : 23-25.

Inyang, C.U., dan U.M. Zakari. 2008. Effect of Germination and Fermentation of Pearl Millet on Proximate, Chemichal and Sensory Properties of Instant "Fura".Pakistan Journal of Nutrition. Vol. 7(1) : 9-12.

Megat, R.M.R., A. Azrina, dan M.E. Nohaizan. 2016. Effect of Germination on Total Dietary Fiber and Total Sugar in Selected Legumes. Journal of International Food Research Vol. 23(1) : 258.

Narsih, Yunianta, dan Harijono. 2008. Studi Lama Perendaman dan Lama Perkecambahan Sorghum (Sorghum bicolour L. Moench) untuk Menghasilkan Tepung Rendah Tanin dan Fitat. Jurnal Teknologi Pertanian. Vol. 9(3) : 177.

Onyango, C.A., S.O. Ochanda., M.A. Mwasaru., J.K.Ochieng., F.M. Mathoko., dan J.N. Kinyuru. 2013. Effects of Malting and Fermentation on Anti-Nutrient Reduction and Protein Digestibility of Red Sorghum, White Sorghum and Pearl Millet. Journal of Food Research. Vol 2(1):42-44.

Rooney, L.W. dan S. Serna. 2000. Handbook of Cereal Science and Technology. Marcel Dekker. New York. 149-175.

Sarita dan E. Singh. 2016. Millet's Anti-nutrients and Their Therapeutic effects. The Pharma Innovation Journal. Vol 5(8) : 43-44.

Satyati. 2001. Peningkatan Kandungan Tokoferol dan Potensi Antioksidatif Mi Instan dengan Suplementasi Menggunakan Pasta Kecambah Kacang Hijau. Thesis. Pascasarjana UGM. Yogyakarta.

Shah, Syed A., A. Zeb, T. Masood, N. Noreen, S.J. Abbas, M. Samilullah, M.A. Alim, dan A. Muhammad. 2011. Effects of Sprouting Time on Biochemichal and Nutritional Qualitis of Mungbean Varieties. African Journal of Agricutural Research. Vol 6(22) : 
5094.

Soekarto, S.T. 1985. Penilaian Organoleptik Untuk Industri Pangan dan Pertanian. Bharata Karya Aksara, Jakarta.

Sudarmadji, S.B., Haryono, dan Suhardi. 1997. Prosedur Analisa Untuk Bahan Makanan dan Pertanian. Liberty, Yogyakarta.

Winarno, F.G. 2004. Kimia Pangan dan Gizi. PT. Gramedia Pustaka Utama. Jakarta. 